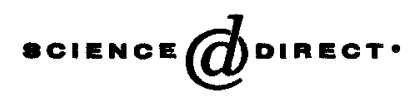

Life Sciences 76 (2005) 1061-1072

\title{
Different sensitivity of PPAR $\alpha$ gene expression to nutritional changes in liver of suckling and adult rats
}

\author{
Maribel Panadero, Emilio Herrera, Carlos Bocos* \\ Facultad de Ciencias Experimentales y de la Salud, Universidad San Pablo-CEU, Monteprincipe, \\ Ctra. Boadilla del Monte Km. 5,300, 28668 Boadilla del Monte, Madrid, Spain
}

Received 18 March 2004; accepted 14 October 2004

\begin{abstract}
The amount of peroxisome proliferator-activated receptor- $\alpha$ (PPAR $\alpha)$ protein was markedly augmented in the liver of suckling rats compared to adult rats. This different PPAR $\alpha$ abundance was used to study the sensitivity to nutritional changes in the expression and activity of this receptor. Thus, 10-day-old and adult rats were orally given either glucose, Intralipid or a combination of both diets, and liver mRNA levels of PPAR $\alpha$ and the PPAR related genes, acyl-CoA oxidase (ACO) and phosphoenolpyruvate carboxykinase (PEPCK), and plasma metabolites were measured. In neonates, the expression of PPAR $\alpha$ and ACO was seen to increase when the level of FFA in plasma was also high, unless an elevated level of insulin was also present. However, this fatty acid-induced effect was not detected in adult rats. On the contrary, the hepatic expression of PEPCK was modulated by the nutritional changes similarly in both neonates and adult rats. Thus, it may be concluded that the expression of the PPAR $\alpha$ gene in adult rats seems to be less sensitive to nutritional changes than in neonates.
\end{abstract}

(C) 2004 Elsevier Inc. All rights reserved.

Keywords: PPAR $\alpha$; mRNA levels; Lipids; Insulin; Suckling; Adult rat

\section{Introduction}

Peroxisome proliferator-activated receptors (PPAR) are members of the steroid nuclear receptor superfamily, which is a large class of ligand-activated transcription factors regulating gene expression. These receptors, after binding peroxisome proliferator compounds or fatty acids, are activated and

* Corresponding author. Tel.: +34 9137247 60; fax: +34913510496.

E-mail address: carbocos@ceu.es (C. Bocos).

0024-3205/\$ - see front matter (C) 2004 Elsevier Inc. All rights reserved. doi:10.1016/j.1fs.2004.10.018 
regulate the expression of genes related to lipid metabolism (Bocos et al., 1995, for a review; Forman et al., 1997), such as peroxisomal $\beta$-oxidation, gluconeogenesis, lipid transport, and ketogenesis. So far, three PPAR subtypes have been identified in rat: PPAR $\alpha, \operatorname{PPAR} \beta$ and PPAR $\gamma$. The isoform $\alpha$ is the best-characterized and it is primarily expressed in tissues that have a high level of fatty acid catabolism such as liver (Braissant et al., 1996), being involved in the modulation of fatty acid oxidation.

Activation of PPAR $\alpha$ and consequently the corresponding modulation of the expression of its target genes, can be due to an induction of PPAR $\alpha$ mRNA and protein and/or an increase in PPAR $\alpha$ ligand activation (Kersten et al., 1999). However, whereas the latter has been extensively studied, the regulation of PPAR $\alpha$ expression has been poorly described to date, and only glucocorticoids seem to show a clear effect (Lemberger et al., 1994). Most studies have been carried out in vitro and conflicting results have been reported regarding the regulation of PPAR $\alpha$ expression by either insulin (Sterchele et al., 1996; Steineger et al., 1994; Inoue et al., 1998) or fatty acids (Steineger et al., 1994; Takase et al., 1998). Interestingly, there has also been speculation that relative amounts of PPAR $\alpha$ might mediate different responses in gene expression. Thus, it has been proposed that whereas high levels of PPAR $\alpha$ would modulate both the lipid homeostasis gene expression (i.e. LPL, apo-AI) and genes associated with the peroxisome proliferation (i.e. ACO, bifunctional enzyme), low amounts of PPAR $\alpha$ would only act on the regulation of the former (Holden and Tugwood, 1999). In agreement with this, the guinea pig expresses active PPAR $\alpha$ in the liver at reduced levels, and in fact is a non-responsive species to peroxisome proliferation (Tugwood et al., 1998). Furthermore, addition of PPAR $\alpha$ to guinea-pig hepatocytes confers increased responsiveness to peroxisome proliferators (Macdonald et al., 1998). Hepatic expression of PPAR $\alpha$ in humans is also low, whereas in mice and rats it is high, suggesting that species differences in response to peroxisome proliferators may be due to the quantity of PPAR $\alpha$ (Macdonald et al., 1998). Thus, it has been reported that the response to PPAR $\alpha$ affects different genes in human versus rat hepatocytes (Hsu et al., 2001; Lawrence et al., 2001). However, HepG2 cells engineered to express PPAR $\alpha$ at concentrations similar to mouse liver, were kept refractory to peroxisome proliferation (Hsu et al., 2001; Lawrence et al., 2001). Nevertheless, differences between HepG2 cells and normal human liver in the expression of critical or auxiliary factors could limit the capacity of PPAR to regulate the expression of genes encoding for the peroxisomal fatty acid oxidation pathway (Hsu et al., 2001).

In a previous study, we found that both the amount of PPAR $\alpha$ receptor and the PPAR $\alpha$ mRNA levels vary during development in rat, reaching a high value during the suckling period, and declining in 30 day-old rats (Panadero et al., 2000). Latterly, we also found a higher expression in neonates than in 30day-old rats, and this difference was related to the lipid-rich milk intake (Panadero et al., 2001). Thus, dietary fat was able to markedly increase the hepatic PPAR $\alpha$ expression at the neonatal stage, unless plasma insulin levels were high (Panadero et al., 2001). However, whereas Suruga et al. (1995) did not find any response of jejunal PPAR $\alpha$ mRNA level in adult rats to force-feeding a high-fat diet, Steineger et al. (1994) reported an induction of PPAR mRNA expression in adult rat hepatocytes by fatty acids, suggesting that a positive effect of fatty acids on PPAR $\alpha$ expression might be liver-specific (Suruga et al., 1995).

By following a force-feeding protocol, the present study was carried out on neonates and adult rats in order to investigate whether the control on PPAR expression by means of fatty acids is dependent on the amount of PPAR $\alpha$ receptor. The study was also extended to determine the expression of PEPCK mRNA, which is known to be responsive to nutritional manipulations both in suckling (Lyonnet et al., 1988) and adults rats (Antras-Ferry et al., 1995). 


\section{Methods}

\section{Animals}

Female Sprague-Dawley rats weighing 160-190 g were fed ad libitum standard rat chow (B and K Universal, Barcelona, Spain) and mated. The experimental protocol was approved by the Animal Research Committee of the University San Pablo-CEU (Madrid, Spain). Mothers were allowed to deliver and on the day of birth, each suckling litter was reduced to nine pups per mother. Ten-dayold suckling rats were separated from their mothers, maintained at $37{ }^{\circ} \mathrm{C}$, in high humidity, and subjected to oral force-feeding three times (at 10.00 a.m., 11.00 a.m., and 13.00 p.m.) with 10-20 $\mu \mathrm{L} / \mathrm{g}$ of body weight of a solution containing either $25 \%$ glucose, $10 \%$ Intralipid (emulsion of soybean oil), glucose plus Intralipid or the medium (bidistillated water). The animals were decapitated two hours after the last administration. In all cases, the liver was immediately removed, placed in liquid nitrogen and stored at $-70^{\circ} \mathrm{C}$ until analysis. Blood was collected from the neck into EDTA-containing receptacles and after centrifugation, plasma was kept at $-20{ }^{\circ} \mathrm{C}$ until processed for insulin and free fatty acid (FFA) analysis using commercial kits (DiaSorin, USA and Wako, Germany, respectively). Ninety-day-old male rats weighing 200-225 g received the same treatment and were always studied in parallel. In some experiments, after a $24 \mathrm{~h}$ fast adult rats were subjected to the same protocol as above mentioned for the animals which received the medium, making a total of 29-h fasting.

\section{$R N A$ analysis}

Total cellular RNA was prepared from the liver of individual animals. Total RNA was isolated by a modification of the guanidium isothiocyanate method using Ultraspec RNA according to the manufacturer's instructions (Biotecx Labs, Houston, TX). Total RNA concentration was determined by absorbance measurement at $260 \mathrm{~nm}$. The $260 / 280$ absorption ratio of all samples was between 1.8 and 2.0. Ten, 20 and $30 \mu \mathrm{g}$ of total RNA was denatured, spotted, and fixed to a nylon membrane. The cDNA probes for dot blot analysis were labeled with $\left[\alpha-{ }^{32} \mathrm{P}\right] \mathrm{dCTP}$ using the random primer DNA labeling kit provided by Amersham. Probes used were: $1.1 \mathrm{~kb}$ Pst I fragment of rat peroxisomal acylCoA oxidase (ACO) cDNA (kindly supplied by Dr. H. N. Sorensen, University of Oslo, and with the permission of Dr. T. Osumi, Humeji Institute of Technology, Hyogo, Japan), $1.6 \mathrm{~kb}$ Eco RI fragment of rat PPAR $\alpha$ cDNA (a generous gift from Dr. J-Å Gustafsson, Karolinska Institute, Huddinge, Sweden) and a fragment of rat $\beta$-actin cDNA (kindly supplied by Dr. D. Landin, INSERM U317, Toulouse, France). Around $25 \mu \mathrm{g}$ of total RNA was also denatured, separated on $1.2 \%$ agarose gels and transferred to nylon membranes in $20 \times$ SSC. The cDNA probe for Northern blot analysis was a rat PEPCK cDNA fragment (kindly supplied by Dr. D. K. Granner, Vanderbilt University Medical Center, Nashville, USA). Blots were prehybridized at $42{ }^{\circ} \mathrm{C}$ for $2 \mathrm{~h}$ and hybridized overnight at the same temperature. Washing conditions were $2 \times \mathrm{SSC}, 0.1 \% \mathrm{SDS}$ at $42{ }^{\circ} \mathrm{C}$ for $15 \mathrm{~min}$ twice for $\operatorname{PPAR} \alpha$, and $0.1 \times \mathrm{SSC}, 0.1 \% \mathrm{SDS}$ at $53{ }^{\circ} \mathrm{C}$ for $15 \mathrm{~min}$ three times for the other probes. Membranes were then exposed to Kodak X-OMAT films at $-70{ }^{\circ} \mathrm{C}$ from $1 \mathrm{~h}$ to 3 days. Filters were stripped of label at $75-80{ }^{\circ} \mathrm{C}$ for $1 \mathrm{~h}$ with $0.1 \mathrm{SSC}, 0.5 \% \mathrm{SDS}, 0.1 \%$ tetrasodium pyrophosphate and then rehybridized. For dot blot analysis, linearity of the relationship between signal intensity and RNA concentration was confirmed for each sample and probe. 


\section{Immunoblotting}

Ten-day-old and 90-day-old non-forced-fed rats were sacrified at $10 \mathrm{a} . \mathrm{m}$. and an aliquot of their livers was homogenized in a buffer containing $25 \mathrm{mM}$ MOPS, $1 \mathrm{mM}$ EDTA, $2 \mathrm{mM}$ DTT, $0.4 \mathrm{M} \mathrm{KCl,} \mathrm{pH} 7.9$, and $0.2 \mathrm{mM}$ PMSF. Sixty $\mu \mathrm{g}$ of total protein of liver homogenate were denatured and subjected to SDSPAGE. Proteins were transferred to nitrocellulose and visualized by Ponceau Red to confirm transfer. Blots were incubated with a polyclonal antibody to PPAR $\alpha$ (Passilly et al., 1999) (kindly supplied by Dr. M. Dauça, University Henri Poincaré, Nancy, France), followed by a peroxidase-conjugated goat antirabbit antibody (Sigma) and the immunoreactive bands were visualized by enhanced chemiluminescence (ECL, Amersham).

\section{Statistical analysis}

Data are expressed as mean \pm standard error. Results were subjected to a one-way analysis of variance (ANOVA), differences in mean values among groups were tested using the Tukey multiple range test, and were considered statistically different at $P<0.05$. For results of plasma insulin levels, the Mann-Whitney $U$ test was used. Where applicable, the comparison between adult and suckling rats or between glucose and fasted-29-hour groups were made by the Student $t$ test.

\section{Results and discussion}

\section{Hepatic PPAR protein of suckling and adult rats}

The relative amount of PPAR $\alpha$ receptor in the liver of suckling rats (10 days old) was found to be significantly higher than in adult rats (three months old) (Fig. 1). This finding agrees with previous reports from us (Panadero et al., 2000, 2001) and others (Gruppuso et al., 2000), demonstrating that PPAR $\alpha$ in rat liver displays higher mRNA level during the suckling period than at the adult stage. These findings also agree with the fact that we previously found, that PPAR $\alpha$ protein appeared more abundant in the liver of suckling than in weaning rats (Panadero et al., 2000). Thus, this age dependent difference found in the level of PPAR $\alpha$ protein in rat may be used to determine whether the grade of responsiveness of this receptor to fatty acids is dependent or not on the PPAR $\alpha$ amount in the tissue. Although this conclusion was derived from studies using species which differ in their responses to PPAR $\alpha$ activators (Holden and Tugwood, 1999; Tugwood et al., 1998; Macdonald et al., 1998; Hsu et al., 2001; Lawrence et al., 2001), the possibility also exists that these observed differences between non-responsive and sensitive species might just be the result of a species-specific difference. By using animals from the same species and strain but having different quantities of PPAR $\alpha$, such a possibility could be determined.

\section{Nutritionally induced changes in plasma insulin and FFA levels in suckling and adult rats}

In order to determine whether the regulation of PPAR $\alpha$ expression and activity by nutritional factors is similar between neonatal and adult rats, despite displaying different PPAR $\alpha$ protein abundance, ten-dayold and ninety-day-old rats were given orally either glucose, Intralipid, both or kept fasted for the 5-h period (receiving just the medium, bidistillated water). As shown in Table 1, plasma FFA were higher in 
PPAR $\alpha$

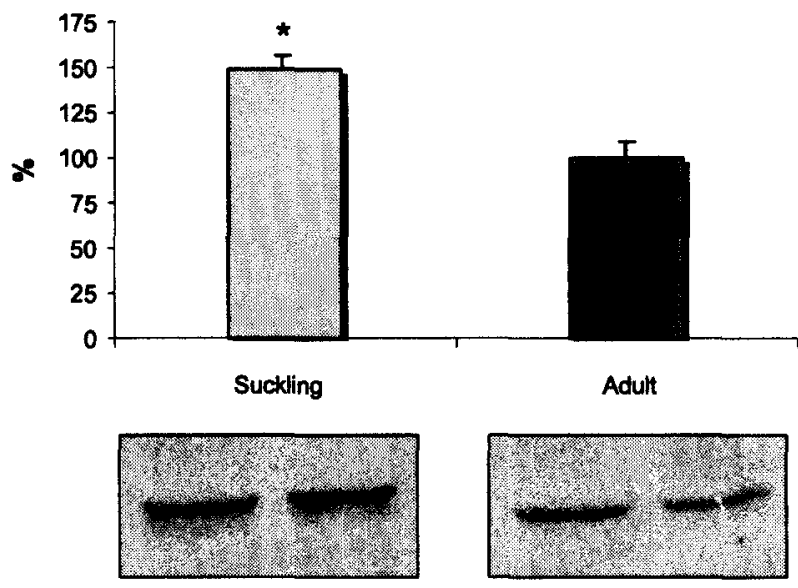

Fig. 1. Immunoblot of total liver homogenates from suckling and adult non-forced-fed rats incubated with an antibody against PPAR $\alpha$, followed by ECL visualization. Adults were set to $100 \%$. The diagram shows the results of the densitometric analysis. The bars represent mean $\pm \mathrm{SE}$ of four animals. Statistically ( $t$-test) significant difference is indicated by asterisk $\left({ }^{*}, P<0.05\right)$.

suckling rats receiving Intralipid, glucose plus Intralipid, or the medium (i.e. kept fasted), as compared to those receiving only glucose. Similar results were observed in adult rats (Table 1). For plasma insulin, both in suckling and adult rats, the levels were significantly higher in the glucose plus Intralipid group than in any of the other conditions studied (Table 1).

\section{Nutritionally induced changes in PPAR $\alpha$ mRNA in liver of suckling and adult rats}

As shown in Fig. 2, the expression of hepatic PPAR $\alpha$ was higher when the neonates were fed with a high lipid diet (Intralipid) as compared to those fed glucose. Surprisingly, this induction was not detected in the adult animals, despite the high FFA levels found in the Intralipid group (Table 1). This finding was in accordance with the reported lack of effect of unsaturated fatty acid on the expression of PPAR $\alpha$ in

Table 1

Effect of force-feeding with either glucose, Intralipid, glucose plus Intralipid or the medium (bidistillated water) on plasma insulin and FFA levels in suckling and adult rats

\begin{tabular}{llrl}
\hline & Oral treatment & Insulin $(\mu \mathrm{U} / \mathrm{mL})$ & FFA $(\mu \mathrm{M})$ \\
\hline Suckling rats & Glucose & $8.9 \pm 2.3^{\mathrm{b}}$ & $375 \pm 88^{\mathrm{a}}$ \\
& Intralipid & $4.1 \pm 1.4^{\mathrm{a}}$ & $884 \pm 123^{\mathrm{b}}$ \\
& Glucose + Intralipid & $27.3 \pm 5.1^{\mathrm{c}}$ & $818 \pm 92^{\mathrm{b}}$ \\
Medult rats & $7.1 \pm 2.1^{\mathrm{ab}}$ & $772 \pm 73^{\mathrm{b}}$ \\
& Glucose & $6.9 \pm 1.4^{\mathrm{a}}$ & $355 \pm 22^{\mathrm{a}}$ \\
& Intralipid & $6.8 \pm 1.4^{\mathrm{a}}$ & $619 \pm 50^{\mathrm{c}}$ \\
& Glucose + Intralipid & $20.9 \pm 4.7^{\mathrm{b}}$ & $435 \pm 24^{\mathrm{b}}$ \\
& Medium & $8.2 \pm 2.8^{\mathrm{a}}$ & $484 \pm 79^{\mathrm{abc}}$ \\
\hline
\end{tabular}

Values are means \pm S.E of 7-10 suckling rats/group or 4 adult rats/group. For each experimental group, the superscript letters correspond to the statistical comparisons between the different nutritional oral treatments for each parameter (values not sharing a common superscript letter are significantly different at $P<0.05$ ). 


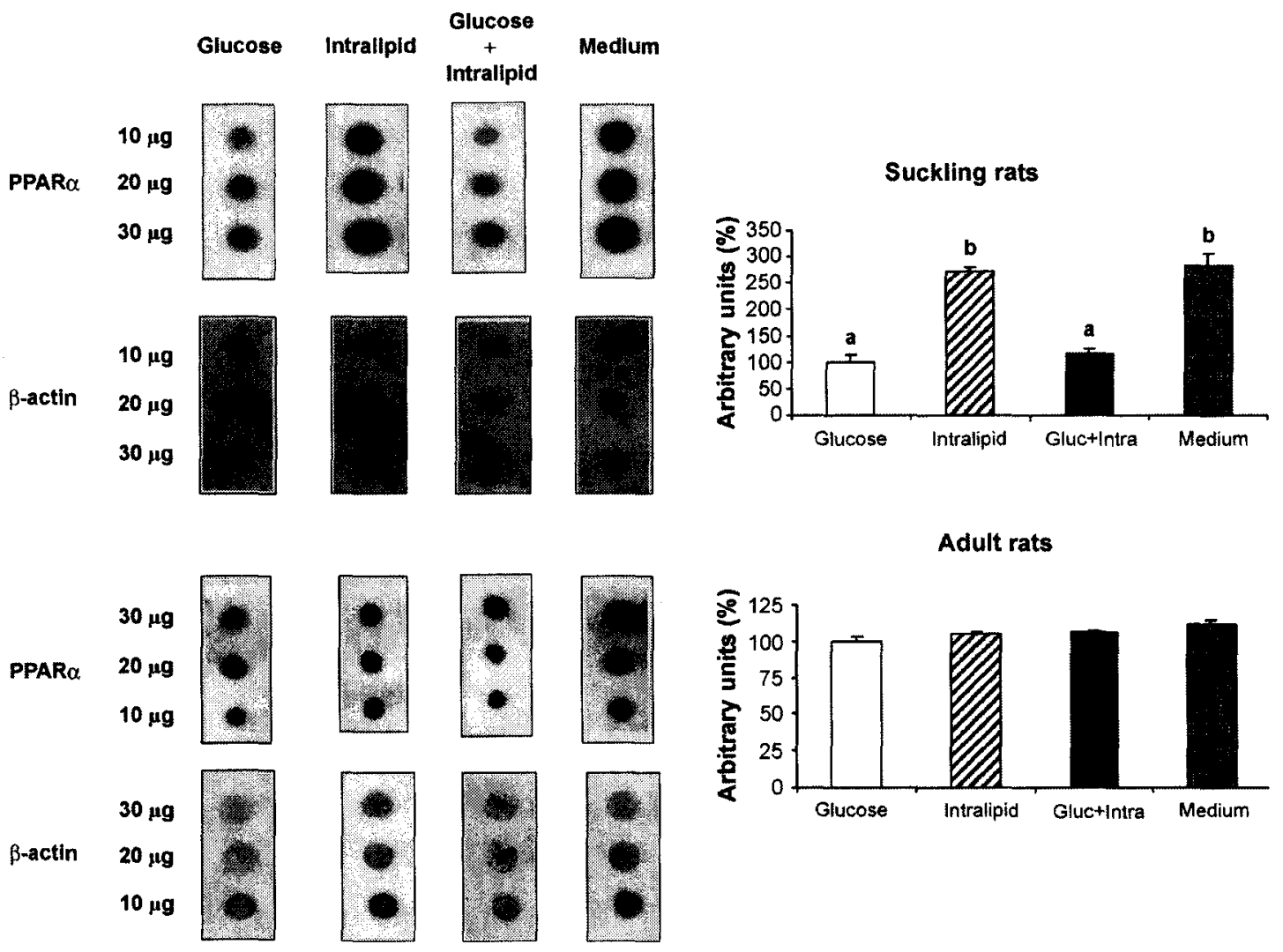

Fig. 2. Effect of force-feeding with either glucose, Intralipid, glucose plus Intralipid, or medium (bidistillated water) on hepatic expression of PPAR $\alpha$ in both 10-day-old and 90-day-old rats. Left. Representative dot-blot analysis of mRNA of PPAR $\alpha$ and $\beta-$ actin, prepared from livers of rats from each group are shown. The amount of RNA spotted is indicated on the left of each panel. Right. Relative amount of liver PPAR $\alpha$ obtained by densitometric scanning of the blots and normalized against actin was represented using arbitrary units, considering $100 \%$ the mean value in liver of glucose fed rats. Each value represents the mean $\pm \mathrm{SE}$ of four animals. Comparison between groups was performed with one-way analysis of variance (ANOVA), and a different letter means statistically significant differences at $P<0.05$.

adult rat jejunum (Suruga et al., 1995) or of dietary lipids on the steady-state levels of PPAR $\alpha$ mRNA in heart and liver (Ouali et al., 2000), discarding tissue-specific response differences. In the suckling rats treated with bidistillated water, which were fasted for $5 \mathrm{~h}$, we also found a significant increase in the hepatic mRNA PPAR $\alpha$ content as compared to animals receiving glucose (Fig. 2), which corresponds with the high levels observed in the plasma FFA of these animals. However, in adult rats this nutritional induction in the abundance of hepatic PPAR $\alpha$ mRNA was not observed. On the other hand, as shown in Fig. 2, in suckling rats when the high lipid intake was administered along with glucose, the expression of PPAR $\alpha$ was not enhanced. Since the FFA level found in this group was similar to that observed in the animals receiving Intralipid, the putative explanation for the lack of effect when glucose is simultaneously used with Intralipid, could be a counteracting effect of the high plasma insulin levels. Although a lack of response to Intralipid plus glucose was also found in adult rats, despite their high FFA levels which were also higher than those from the glucose group (Table 1), this finding may be better 
explained as the result of the lack of effect of FFA on PPAR $\alpha$ expression in these animals than due to a counteracting action of the augmented insulin levels.

\section{Nutritionally induced changes in $m R N A$ of $A C O$ and PEPCK in liver of suckling and adult rats}

In order to check whether the changes described for the PPAR $\alpha$ expression in the liver of either suckling or adult rats subjected to force-feeding with different nutrients were reflected in its target genes, the mRNA expression of ACO was also determined in the same blots. As shown in Fig. 3, ACO mRNA expression was characterized, both in neonates and adult rats, by trends similar in response to the nutritional changes as those found with PPAR $\alpha$ expression. Thus, in neonates the presence of high plasma FFA levels (Table 1) was associated with an augmented ACO expression, presumably through PPAR $\alpha$ (Fig. 3). However, in adult rats elevated FFA levels in the animals receiving Intralipid versus those fed glucose, did not produce any difference in ACO expression between both groups. Similar to these findings, high plasma FFA levels caused by fasting conditions (i.e. those receiving the medium) (Fig. 3) enhanced ACO expression in suckling rats when compared to those having low FFA levels, whereas in adults no differences among the groups were detected. Interestingly, in suckling rats when the high lipid intake (i.e. Intralipid) was administered along with glucose, the expression of $\mathrm{ACO}$, however,

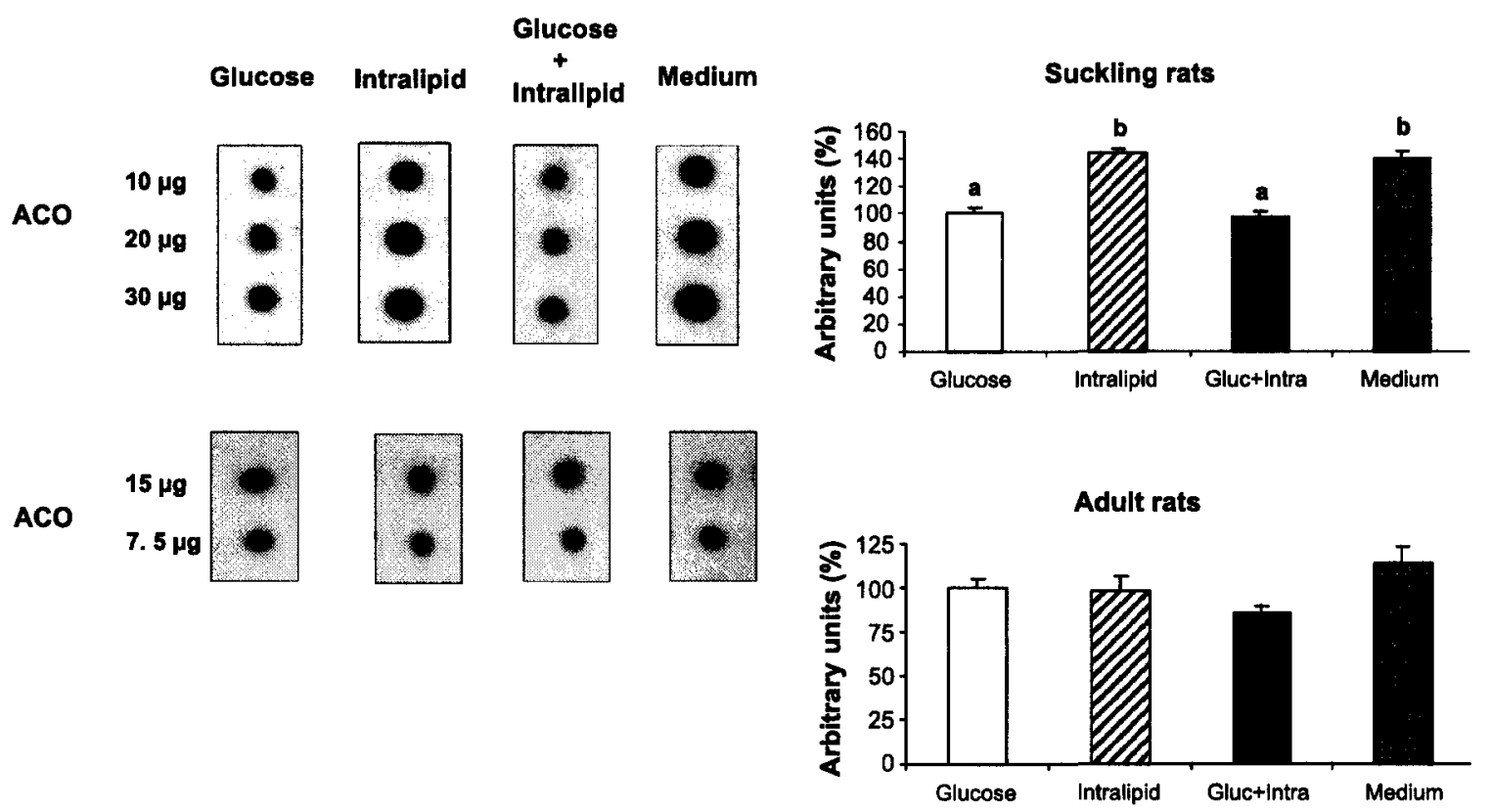

Fig. 3. Effect of force-feeding with either glucose, Intralipid, glucose plus Intralipid, or medium (bidistillated water) on hepatic expression of peroxisomal acyl-CoA oxidase (ACO) in both 10-day-old and 90-day-old rats. Left. Representative dot-blot analysis of ACO mRNA, prepared from livers of rats from each group are shown. The amount of RNA spotted is indicated on the left of each panel. Right. Relative amount of liver ACO obtained by densitometric scanning of the blots and normalized against actin was represented using arbitrary units, considering $100 \%$ the mean value in liver of glucose fed rats. Each value represents the mean $\pm \mathrm{SE}$ of four animals. Comparison between groups was performed with one-way analysis of variance (ANOVA), and a different letter means statistically significant differences at $P<0.05$. Comparison between values of adult rats were not significant. 
was not augmented. Such lack of effect could be due to the fact that the presence of PPAR $\alpha$ in this group was also low (Fig. 2) and possibly not enough to produce an adequate activation by FFA. Nevertheless, the possibility that high plasma insulin levels could be preventing the increase of ACO expression provoked by the elevated plasma FFA levels, cannot be ruled out. In adult rats, neither elevated FFA levels nor high plasma insulin levels (Table 1) did produce any difference in ACO expression in the animals receiving glucose plus Intralipid versus those fed glucose. These findings altogether would therefore show that the expression of the target gene and its receptor is affected in an analogous manner by hormonal and fatty acids, as previously suggested (Steineger et al., 1994; Panadero et al., 2000). Furthermore, these findings for the ACO expression and PPAR $\alpha$ ligands like FFA, would also be in accordance with those reported for UCP-3 expression in skeletal muscle, where the responsiveness of the UCP-3 gene to PPAR $\alpha$ activators was clearly dependent on the expression of the receptor (Brun et al., 1999).

Since the lack of response of ACO and PPAR expression in adult rats to the different nutrition conditions studied could be considered an unefficient effect as a consequence of the short-term feeding with the high lipid diet used here, the expression of PEPCK mRNA, known to be responsive to nutritional manipulations (Lyonnet et al., 1988; Antras-Ferry et al., 1995), was also determined. Furthermore, in previous studies we found that at least during the perinatal period, PEPCK expression presents a similar pattern to the one for PPAR $\alpha$ (Panadero et al., 2000), suggesting a common mechanism of regulation in which high lipid intake may be involved. However, several peroxisome proliferator response elements (PPREs) have been identified in the promoter of PEPCK gene, showing an intermediate PPAR binding activity (Juge-Aubry et al., 1997). As shown in Fig. 4, PEPCK mRNA

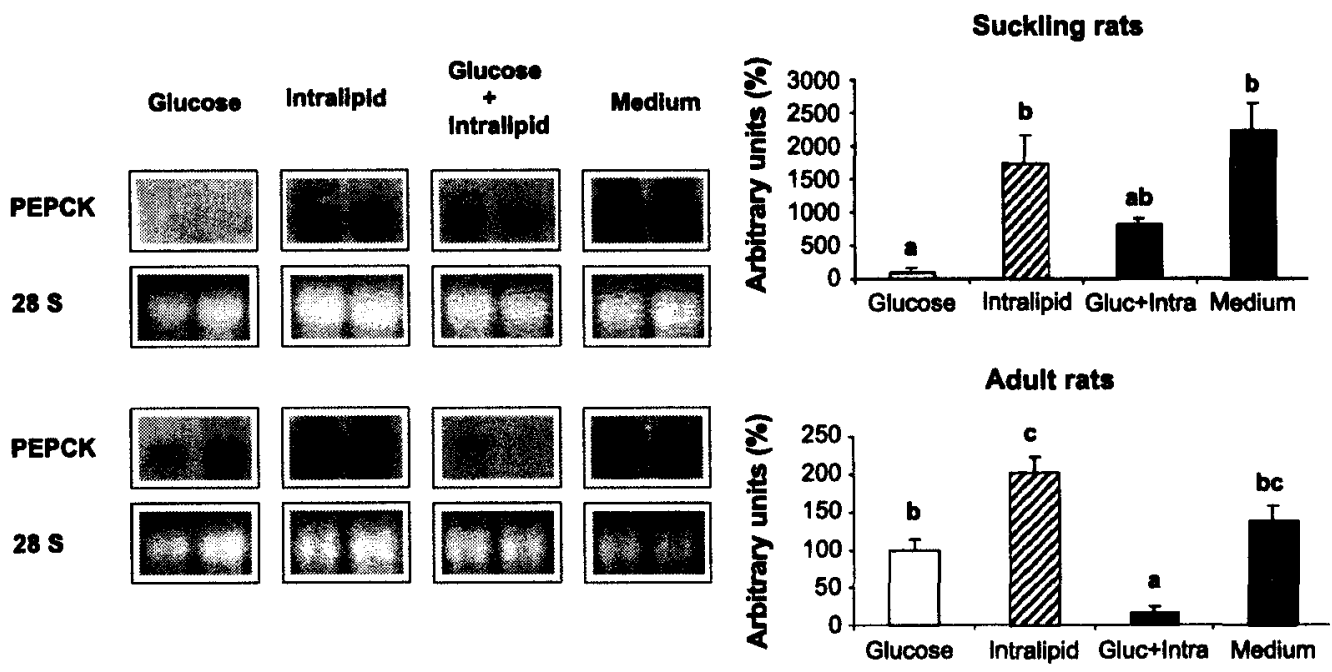

Fig. 4. Effect of force-feeding with either glucose, Intralipid, glucose plus Intralipid, or medium (bidistillated water) on hepatic expression of phosphoenolpyruvate carboxykinase (PEPCK) in both 10-day-old and 90-day-old rats. Left. Representative Northern blot analysis of PEPCK mRNA and 28S ribosomal RNA ethidium bromide staining, prepared from livers of rats from each group are shown. Around $25 \mu \mathrm{g}$ of total RNA were used as indicated in Material and Methods. Right. Relative amount of liver PEPCK obtained by densitometric scanning of the blots and normalized versus 28S ribosomal RNA was represented using arbitrary units, considering $100 \%$ the mean value in liver of glucose fed rats. Each value represents the mean \pm SE of four animals. Comparison between groups was performed with one-way analysis of variance (ANOVA), and different letters means statistically significant differences at $P<0.05$. 
expression in suckling rats showed similar responses to the nutritional changes as those found with PPAR $\alpha$ expression, that is, high levels of FFA (Table 1) stimulated PEPCK expression unless a high level of insulin was also present. However, and very different from the finding of PPAR $\alpha$ and ACO expression, in adult rats PEPCK expression showed a clear response to the nutritional manipulations. In fact, both plasma insulin, negatively, and FFA, positively, modulated PEPCK expression in adult rats (Fig. 4, Table 1). These findings indicate that hepatic PEPCK mRNA levels are regulated in vitro by nutrients and hormones independently of either changes in the PPAR $\alpha$ expression or the age of the animals.

\section{Effect of fasting in $m R N A$ of PPAR,$A C O$ and PEPCK in liver of adult rats}

It could also be argued that the time period, 5 hours, that the animals were without food (only bidistillated water), was not long enough to be considered a fasting period in adult rats, even though we found that the plasma FFA levels were maintained elevated in these animals throughout the study (data not shown). In general, the period of time used for studying the effect of fasting on the expression of PPAR $\alpha$ and target genes in adult rats has typically been between $7.5 \mathrm{~h}$ (Escher et al., 2001) and $24 \mathrm{~h}$ (Kersten et al., 1999). In fact, as shown in Fig. 5, adult rats fasted for 29 hours showed a significant increase in the PPAR $\alpha$ mRNA levels as compared to the animals receiving glucose. The dramatically low levels of plasma insulin $(0.46 \pm 0.15 \mu \mathrm{U} / \mathrm{mL})$ found in these animals along with the high FFA levels $(781 \pm 81 \mu \mathrm{M})$, both values significantly different $(P<0.01)$ than those found in the glucose group (Table 1), would explain the clear induction of PPAR $\alpha$ expression found in these adult rats. These findings altogether may suggest that induction on PPAR expression by FFA could be dependent on the amount of the receptor present (i.e. adult versus suckling rats), unless a PPAR-inducer overload and/or a PPAR-repressor diminution is able to surpass that restriction, as has occurred in 29-hour-fasted rats with
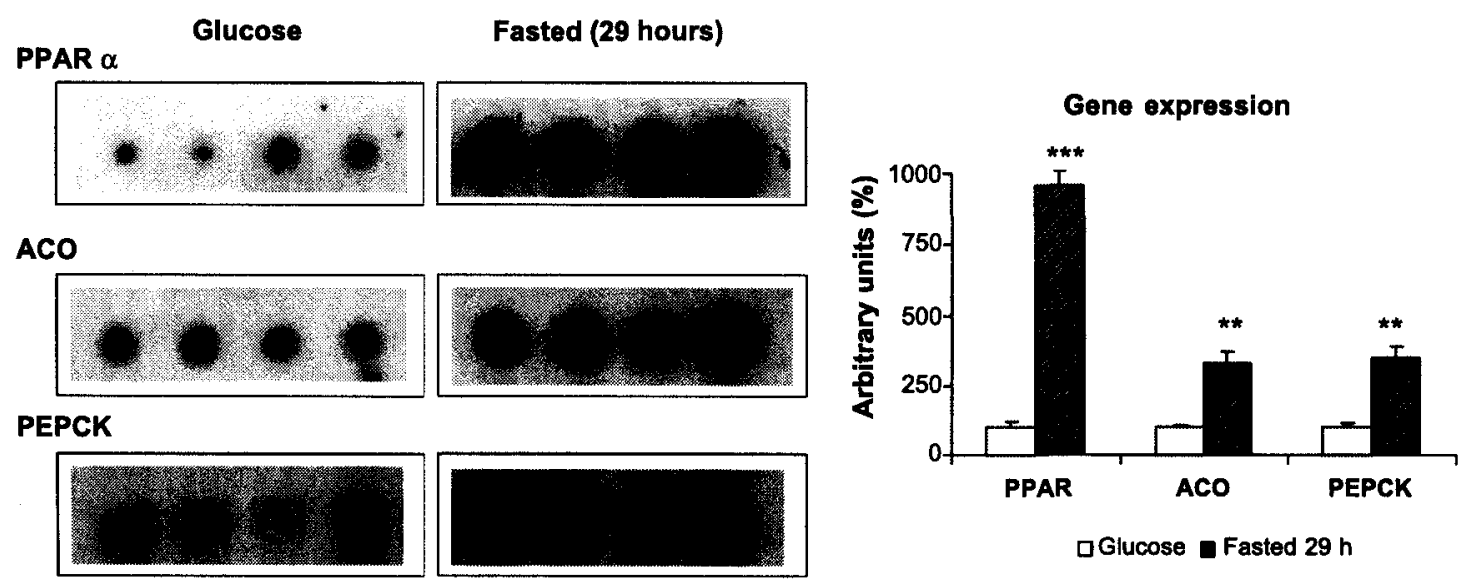

Fig. 5. Effect of fasting for 29 hours on hepatic expression of both PPAR $\alpha$, ACO and PEPCK in 90-day-old rats. Left. Representative dot-blot for PPAR and ACO and Northern blot analysis of PEPCK mRNA, prepared from livers of rats from each group are shown. Right. Relative amount of either PPAR $\alpha$ and ACO normalized with actin or PEPCK corrected by $28 \mathrm{~S}$ ribosomal RNA was represented using arbitrary units, considering $100 \%$ the mean value in liver of glucose fed rats. Each value represents the mean $\pm \mathrm{SE}$ of four animals. Statistically ( $t$-test) significant difference is indicated by asterisk $\left({ }^{*}, P<0.05 ;{ }^{* *}\right.$, $P<0.01$;*** $P<0.001$ ). 
their high FFA and extremely low insulin levels (Fig. 5). Possibly in that same sense, the no-effect found on the ACO expression in adult rats (Fig. 3) would reinforce the idea that a fat-overload of the liver is necessary to obtain a considerable effect on the expression of fatty acid-metabolizing enzymes (Kersten et al., 1999; Panadero et al., 2001). In fact, as shown in Fig. 5, hepatic expression of ACO in adult rats was considerably augmented by fasting for 29 hours, showing that hepatic PPAR in the adult rats studied here was completely functional. On the other hand, in consonance with the results shown in Fig. 4 describing how PEPCK is responsive to nutritional manipulations in adult rats and with previous reports (Lyonnet et al., 1988; Antras-Ferry et al., 1995), the high amount of FFA along with the low levels of insulin found in plasma adult rats subjected to 29 hours fasting, produced a clear induction on PEPCK expression, as shown in Fig. 5.

Finally, the different responses found here to the nutritional manipulations between adult and suckling liver might be related to the different gene response to fasting in liver of PPAR $\alpha$ knockout mice for PEPCK gene, which was preserved, and ACO and PPAR $\alpha$ genes, which on the contrary were blocked (Kersten et al., 1999) and it would be pointing to an involvement of other transcription factors in the regulation of PEPCK gene when PPAR $\alpha$ is lacking or at low level. Nevertheless, in contrast to that, in several reports PEPCK has been assumed as a PPAR target gene (Juge-Aubry et al., 1997; Cassuto et al., 1999; Dana et al., 2001), and therefore, in that case, the findings found here would be in accordance with the Holden and Tugwood hypothesis (Holden and Tugwood, 1999). Thus, the expression of peroxisome proliferation genes (i.e. ACO, PPAR itself) would be sensitive to PPAR ligands when a high level of PPAR $\alpha$ is present, justifying the different sensitivity of PPAR $\alpha$ gene expression to nutritional changes in liver of suckling rats (having high PPAR $\alpha$ level) and adult rats (having low PPAR $\alpha$ level). However, the expression of genes related to lipid and/or carbohydrate metabolism (i.e. PEPCK) would be responsive to activators even when the PPAR $\alpha$ amount was low (as occurs in the adult animals). In summary, present findings would suggest that in humans, the low amount of PPAR $\alpha$ would be limiting and only the genes related to hypolipidemia may be induced upon exposure to ligand. On the contrary, in rodents, the high level of PPAR $\alpha$ would be sufficient to activate both the genes associated to lipid metabolism and the genes related to peroxisome proliferation.

\section{Acknowledgements}

This study has been supported by grants from the Fondo de Investigaciones Sanitarias (FIS 01/0524) and the Universidad San Pablo-CEU (10/01). The authors thank Dr. Antonio Aguilar for providing us with Intralipid, Jose M. Garrido for his help in handling the rats, and Brian Crilly for his editorial help.

\section{References}

Antras-Ferry, J., Robin, P., Robin, D., Forest, C., 1995. Fatty acids and fibrates are potent inducers of transcription of the phosphoenolpyruvate carboxykinase gene in adipocytes. European Journal of Biochemistry 234, 390-396.

Bocos, C., Gottlicher, M., Gearing, K., Banner, C., Enmark, E., Teboul, M., Crickmore, A., Gustafson, J.-A., 1995. Fatty acid activation of peroxisome proliferator-activated receptor (PPAR). Joumal of Steroid Biochemistry and Molecular Biology 53, $467-473$.

Braissant, O., Foufelle, F., Scotto, C., Dauça, M., Wahli, W., 1996. Differential expression of peroxisome proliferator-activated receptor (PPARs): Tissue distribution of PPAR $-\alpha,-\beta$, and $\gamma$ in the adult rat. Endocrinology 137, 354-366. 
Brun, S., Carmona, M.C., Mampel, T., Viñas, O., Giralt, M., Iglesias, R., Villarroya, F,, 1999. Activators of peroxisome proliferator-activated receptor- $\alpha$ induce expression of the uncoupling protein-3 gene in skeletal muscle. A potential mechanism for the lipid intake-dependent activation of uncoupling protein-3 gene expression at birth. Diabetes 48 , $1217-1222$.

Cassuto, H., Aran, A., Cohen, H., Eisenberger, C.L., Reshef, L., 1999. Repression and activation of transcription of phosphoenolpyruvate carboxykinase gene during liver development. FEBS Letters 457 (3), $441-444$.

Dana, S.L., Hoener, P.A., Bilakovics, J.M., Crombie, D.L., Ogilvie, K.M., Kauffman, R.F., Mukherjee, R., Paterniti, J.R., 2001. Peroxisome proliferator-activated receptor subtype-specific regulation of hepatic and peripheral gene expression in the Zucker diabetic fatty rat. Metabolism 50 (8), 963-971.

Escher, P., Braissant, O., Basu-Modak, S., Michalik, L., Wahli, W., Desvergne, B., 2001. Rat PPARs: quantitative analysis in adult rat tissues and regulation in fasting and refeeding. Endocrinology 142 (10), 4195-4202.

Forman, B.M., Chen, J., Evans, R.M., 1997. Hypolipidemic drugs, polyunsaturated fatty acids, and eicosanoids are ligands for peroxisome proliferator-activated receptors $\alpha$ and $\delta$. Proceedings of the National Academy of Sciences USA 94, $4312-4317$.

Gruppuso, P.A., Boylan, J.M., Vaslet, C.A., 2000. Identification of candidate growth-regulation genes that are overexpression in late gestation fetal liver in the rat. Biochimica et Biophysica Acta 1494, 242-247.

Holden, P.R., Tugwood, J.D., 1999. Peroxisome proliferator-activated receptor alpha: role in rodent liver cancer and species differences. Journal of Molecular Endocrinology 22, 1-8.

Hsu, M.-H., Savas, Ü., Griffin, K.J., Johnson, E.F., 2001. Identification of peroxisome proliferator-responsive human genes by elevated expression of the peroxisome proliferator-activated receptor alpha in HepG2 cells. Journal of Biological Chemistry $276(30), 27950-27958$.

Inoue, I., Shino, K., Noji, S., Awata, T., Katayama, S., 1998. Expression of peroxisome proliferator-activated receptor (PPAR $\alpha$ ) in primary cultures of human vascular endothelial cells. Biochemical and Biophysical Research Communications 246, 370-374.

Juge-Aubry, C., Pernin, A., Favez, T., Burger, A.G., Wahli, W., Meier, C.A., Desvergne, B., 1997. DNA binding properties of peroxisome proliferator-activated receptor subtypes on various natural peroxisome proliferator response elements. Journal of Biological Chemistry 272 (40), 25252-25259.

Kersten, S., Seydoux, J., Peters, J.M., Gonzalez, F.J., Desvergne, B., Wahli, W., 1999. Peroxisome proliferator-activated receptor $\alpha$ mediates the adaptative response to fasting. Journal of Clinical Investigation 103, $1489-1498$.

Lawrence, J.W., Li, Y., Chen, S., deLuca, J.G., Berger, J.P., Umbenhauer, D.R., Moller, D.E., Zhou, G., 2001. Differential gene regulation in human versus rodent hepatocytes by peroxisome proliferator-activated receptor (PPAR) alpha. PPAR alpha fails to induce peroxisome proliferation-associated genes in human cells independently of the level of receptor expression. Journal of Biological Chemistry 276 (34), 31521-31527.

Lemberger, T., Staels, B., Saladin, R., Desvergne, B., Auwerx, J., Wahli, W., 1994. Regulation of the peroxisome proliferatoractivated receptor $\alpha$ gene by glucocorticoids. Journal of Biological Chemistry 269, 24527-24530.

Lyonnet, S., Coupé, C., Girard, J., Kahn, A., Munnich, A., 1988. In vivo regulation of glycolytic and gluconeogenic enzyme gene expression in newborn rat liver. Journal of Clinical Investigation 81, 1682-1689.

Macdonald, N., Holden, P.R., Roberts, R.A., 1998. Addition of peroxisome proliferator activated receptor $\alpha$ to guinea pig hepatocytes confers increased responsiveness to peroxisome proliferators. Cancer Research 59, 4776-4780.

Ouali, F., Djouadi, F., Merlet-Bénichou, C., Riveau, B., Bastin, J., 2000. Regulation of fatty acid transport protein and mitochondrial and peroxisomal beta-oxidation gene expression by fatty acids in developing rats. Pediatric Research 48 (5), 691-696.

Panadero, M.I., Herrera, E., Bocos, C., 2000. Peroxisome proliferator-activated receptor- $\alpha$ expression in rat liver during postnatal development. Biochimie 82, 723-726.

Panadero, M.I., Herrera, E., Bocos, C., 2001. Nutritionally induced changes in the peroxisome proliferator-activated receptor- $\alpha$ gene expression in liver of suckling rats are dependent on insulinaemia. Archives of Biochemistry and Biophysics 394 (2), $182-188$.

Passilly, P., Schohn, H., Jannin, B., Cherkaoui Malki, M., Boscoboinik, D., Dauça, M., Latruffe, N., 1999. Phosphorylation of peroxisome proliferator-activated receptor $\alpha$ in rat Fao cells and stimulation by ciprofibrate. Biochemical Pharmacology 58, $1001-1008$.

Steineger, H.H., Sorensen, H.N., Tugwood, J.D., Skrede, S., Spydevold, O., Gautvik, K.M., 1994. Dexamethasone and insulin demonstrate marked and opposite regulation of the steady-state mRNA level of the peroxisomal proliferator-activated 
receptor (PPAR) in hepatic cells. Hormonal modulation of fatty-acid induced transcription. European Journal of Biochemistry 225, 967-974.

Sterchele, P.F., Sun, H., Peterson, R.E., Vanden Heuvel, J.P., 1996. Regulation of peroxisome proliferator-activated receptoralpha mRNA in rat liver. Archives of Biochemistry and Biophysics 326, 281-289.

Suruga, K., Suzuki, R., Goda, T., Takase, S., 1995. Unsaturated fatty acids regulate gene expression of cellular retinol-binding protein, type II in rat jejunum. Journal of Nutrition 125, 2039-2044.

Takase, S., Tanaka, K., Suruga, K., Kitagawa, M., Igarashi, M., Goda, T., 1998. Dietary fatty acids are possible key determinants of cellular retinal-biding protein II gene expression. American Journal of Physiology 274, G626-G632.

Tugwood, J.D., Holden, P.R., James, N.H., Prince, R.A., Roberts, R.A., 1998. A peroxisome proliferator-activated receptor alpha (PPAR alpha) cDNA cloned from guinea-pig liver encodes a protein with similar properties to the mouse PPARalpha: implications for species differences in responses to peroxisome proliferators. Archives of Toxicology 72, 169-177. 